\title{
Legal challenges of 5G Mobile Technology in the European Union -Strategic Environmental Assessments \& necessary update of the EIA Directive
}

\author{
Maria Baumgartner* \\ Landscape planner, Engineering office for Landscape planning and Landscape architecture in Graz, Austria
}

*Corresponding author: Maria Baumgartner, landscape planner, Engineering office for Landscape planning and Landscape architecture in Graz, Austria.
Received Date: May 18, 2020

Published Date: June 03, 2020

\begin{abstract}
Do plans and programs for the comprehensive expansion of the $5 \mathrm{G}$ network in the member states of the European Union require the implementation of Strategic Environmental Assessments? To answer this question, the relevant directives at Union level were analyzed. In addition research on the effects of mobile communications technology was done. The result shows that Strategic Environmental Assessments are required in the member states. Also, a regulatory deficit in the European Union's Environmental Impact Directive was revealed.
\end{abstract}

Keywords: 5G; Mobile communication; Cellular technology; Wireless technology; European union; Environment; Health; Impact assessment

Abbreviations: 5G: 5th generation of mobile phone technology; EIA: Environmental Impact Assessment; SEA: Strategic Environmental Assessment; EU: European union

\section{Introduction}

The $5^{\text {th }}$ generation of mobile phone technology $(5 \mathrm{G})$ is on the rise worldwide, including the European Union (EU). It aims to transport large amounts of data quickly and promises great economic potential and profits. The high-frequency waves (socalled cell phone radiation) used for this are sent across the globe and penetrate houses, landscapes and people. What about the legal framework for this? Is it really permissible to roll out this technology level across the EU without any environmental assessment?

\section{Methods}

In order to answer this question, the relevant EU directives were analyzed. In addition, publications on the effects of mobile radio technology in general and $5 \mathrm{G}$ in particular were regarded.

\section{Results}

The high-frequency waves emitted by $5 G$ are among the emissions that the International Agency for Research on Cancer
(IARC), an organization of the World Health Organization (WHO), classifies as potentially carcinogenic [1]. In Italy, the connection between cell phone radiation and cancer was already confirmed by the highest courts in 2012 [2]. The spectrum of action of high-frequency waves is very broad; besides humans, plants and animals may also be severely affected [3]. In addition, mobile phone technology and in particular the planned massive expansion of the 5G network are highly climate-effective [4]. According to Directive 2001/42/EC (SEA Directive) of the European Parliament and Council, plans and programs that are likely to have significant environmental impacts are to be subjected to an assessment of their environmental impacts (Strategic Environmental Assessment, SEA). According to Article 3 (2) a) of the referenced directive, this also includes plans and programs in the field of telecommunications. An assessment is necessary if these plans and programs set the framework for projects that are subject to an Environmental Impact Assessment in accordance with Annexes 
I and II to Directive 85/337/EEC (EIA Directive) or for those in accordance with Article 3 (2) b) the SEA Directive considers an examination according to Article 6 or 7 of the Directive 92/43/EEC (Flora-Fauna-Habitats Directive) necessary in view of their likely effects. In addition, in accordance with Article 3 (4) of the SEA Directive, the EU member states have the option of subjecting plans and programs not covered by Article 3 (2) a) or b) to a Strategic Environmental Assessment if these plans and programs provide the framework for future approval projects that are likely to have significant environmental impacts. According to the current legal status, the obligation to carry out a SEA arises primarily from Article 3 (2) b) of the SEA Directive when the 5G technology is rolled out across the board. This is due to the probable effects of mobile phone radiation on living beings and habitats (Natura 2000 areas), which are protected in accordance with the Flora-Fauna-Habitat Directive. Corresponding to Article 6 of the SEA Directive, the public is to be involved in the SEA procedure. Regarding Article 3 (2) a) of the SEA Directive, a lack of regulation arises in the EIA Directive, since the area of telecommunications is not covered therein, although Article 3 (2) a) of the SEA Directive expressly sees a need for testing in this regard. This deficit results from the different timing of the two directives and should be remedied quickly at European level. In the meantime, the member states of the EU can help themselves to take into account the effects of $5 \mathrm{G}$ technology on people, plants, animals and habitats outside the scope of the Flora-Fauna-Habitat Directive by implementing a SEA in accordance with Article 3 (4) of the SEA Directive [5-8].

\section{Discussion}

The results of the research make it necessary to subject the previous $5 \mathrm{G}$ technology approval practice in the EU member states to a revision and to take environmental effects into account in addition to technical standards. Due to the necessary involvement of the public in the procedures, increased awareness and discussion can be expected. Until the results of the assessments are available, it is recommended that the further expansion of $5 \mathrm{G}$ technology be put on hold. The public issue of $5 \mathrm{G}$ technology as a whole could lead to greater awareness of the effects of mobile technology on people and the environment.

\section{Conclusion}

The plans and programs for the nationwide expansions of the $5 \mathrm{G}$ network in the European Union require the implementation of Strategic Environmental Assessments in the member states of the EU in accordance with the Directive 2001/42/EC of the European Parliament and Council. The telecommunications sector has to be included in the Environmental Impact Assessment Directive 85/337/EEC.

\section{Acknowledgement}

None.

\section{Conflict of Interest}

No conflict of interest.

\section{References}

1. International Agency for Research on Cancer (IARC) (2019).

2. (2020) Diagnose- Funk - Umwelt- und Verbraucherorganisation zum Schutz vor elektromagnetischer Strahlung e. V.1516.

3. (2020) Diagnose- Funk - Umwelt- und Verbraucherorganisation zum Schutz vor elektromagnetischer Strahlung e. V.1220.

4. Belkhir Lotfi, Elmeligi Ahmed (2018): Assessing ICT global emissions footprint: Trends to 2040 \& recommendations, Journal of Cleaner Production 177(10): 448-463.

5. Deutsche Welle (2018) Anstalt des öffentlichen Rechts.

6. European Council (1985) Directive 85/337/EEC of 27 June 1985 on the assessment of the effects of certain public and private projects on the environment

7. European Council (1992) Directive 92/43/EEC of 21 May 1992 on the conservation of natural habitats and of wild fauna and flora.

8. European Parliament and of the Council (2001) Directive 2001/42/EC of 27 June 2001 on the assessment of the effects of certain plans and programmes on the environment. 